\title{
Komparatiewe Voordeel in die Landbou
}

\section{E Kleynhans}

Skool vir Ekonomie, Geld-en Bankwese, Potchefstroomse Universiteit vir CHO

\section{ABSTRACT}

The object of this paper is to demonstrate the use of an alternative method to measure and quantify international competitiveness. The South African agricultural sector is taken as a case study. The paper builds on Bela Balassa's method (1989) of measuring comparative advantage by means of historically revealed advantage. In practice this method is easy to use, readily applicable and the necessary data are usually available. The results of this measuring excercise are interesting and support the hypotheses that a low level of labour productivity contributes significantly to the low international competitiveness of South African agriculture.

JEL $\mathrm{O} 170$

\section{INLEIDING}

Met die aanvaarding van die Algemene Ooreenkoms op Tariewe en Handel en die toenemende liberalisering van wêreldmarkte, raak dit al hoe belangriker vir lande om te bepaal waar hul komparatiewe voordeel geleẽ is. Die uitfasering van beskermende tariewe lei noodwendig tot spesialisasie in dié bedrywe waarin lande die mededingendste is. Die patroon van 'n land se internasionale handel en die allokasie van hulpbronne behoort gevolglik volgens komparatiewe voordeel gerig te word. Ten einde mededingend te bly is lande nou genoodsaak om koste effektiewe uitvoer moontlikhede te soek en beter produkte teen laer pryse te lewer. Dit impliseer groter doeltreffendheid van die markmeganisme wat uiteindelik tot die ekonomiese ontwikkeling en welvaart van almal behoort by te dra.

Die oogmerk van die artikel is om 'n alternatiewe metode van meting en kwantifisering van internasionale mededingendheid voor te stel. Die praktiese toepassing van die tradisionele teorieë word aansienlik bemoeilik deur werklike data en ander probleme. Om dit te oorkom word daar in hiérdie artikel voortgebou op Balassa (1989) se voorstel dat komparatiewe voordeel aan die

\footnotetext{
- Comparative Advantage in Agriculture
} 
hand van histories geopenbaarde voordeel gemeet kan word. Balassa metode wordas superieur bo tradisionele metodes, soos die van Heckscher-Ohlin beskou, omdat dit prakties maklik uitvoerbaar, meer gepas en die data is meer geredelik beskikbaar is. Die resultate van die meting is interessant en bevestig die hipotese dat die kontinue lae vlak van arbeidsproduktiwiteit in Suid-Afrika 'n sterk bydraende faktor tot die lae internasionale mededingendheid van die land is.

Die Suid-Afrikaanse landbousektor is as 'n gevalle studie gebruik. As ontwikkelende land dra die primêre sektor steeds baie tot die bruto binnelandse produksie by (14\% in 1996), waarvan landbouprodukte 'n groot deel uitmaak (39.6\% in 1996). Aangesien 'n aansienlike hoeveelheid landbouprodukte uitgevoer word, is die bepaling van komparatiewe voordeel belangrik. Dit is veral noodsaaklik aangesien tarief- en invoerbeskerming tans uitgefaseer word en nywerheidsontwikkeling en dienste se aandeel tot die bruto binnelandse produk, relatief tot primêre produkte, toeneem wanneer ekonomiese ontwikkeling in 'n landstreek plaasvind.

Volgens die wet van komparatiewe voordeel sal lande baat by internasionale spesialisasie en vryhandel. Internasionale spesialisasie in landbou hou talle probleme en gevare vir 'n land in. Sikliese prysskommelinge, tegnologiese vervanging van produksie en biologiese vernietiging maak dit dikwels moeilik om buitelandse betaalmiddele te verkry en te behou. Sikliese opswaai in primêre kommoditeitspryse bring groot opbrengste vir 'n land, maar die ekonomie moet genoegsame diversiteit besit sodat dit die sikliese afswaaifases van sekere produkte kan oorleef (Mellor, 1966a: 109-110).

Die bydra wat die landbousektor tot Suid-Afrika se produksie en uitvoer maak, asook die skakeleffekte wat daar bestaan (sien Van Rooyen, 1990; 6) maak die korrekte keuse en ontwikkeling van bedrywe, waarin komparatiewe voordeel bestaan noodsaaklik. Dit besit die potensiaal om aansienlik tot ekonomiese groei in Suid-Afrika by te dra.

\section{TEORETIESE BEGINSELS}

Volgens die beginsel van komparatiewe voordeel behoort lande in produkte te spesialiseer waarin hul internasionaal relatief meer doelmatig is. Produkte waarvan die produksie minder doelmatig is, behoort eerder ingevoer te word.

Die beginsels van komparatiewe voordeel word ten beste begryp indien dit as reaksie teen die Merkantilisme gesien word. Volgens die Merkantilisme sal 'n 
land ryk en welvarend word, wanneer dit meer uitvoer as invoer. Die surplus word dan vereffen deur die invloei van goud en waardevolle metale vanaf ander lande. ' $n$ Land kan dan slegs ten koste van 'n ander bevoordeel word, aangesien alle lande nie gelyktydig 'n uitvoersurplus kon handhaaf nie. Die Merkantilisme het gevolglik sterk owerheidsbeheer oor ekonomiese aktiwiteite voorgestaan (Lindert, 1996: 29).

Adam Smith wys daarop dat lande wedersydse voordeel kan behaal uit internasionale handel omdat dit lei tot spesialisasie. Waar een land 'n produk meer doelmatig as ' $n$ ander kan produseer, beskik dit oor absolute voordeel. Produseer die land 'n ander produk minder doelmatig, sal dit vir albei lande voordelig wees om te spesialiseer in die produksie van die kommoditeit waarin dit 'n absolute voordeel het. Deur wedersydse handel sal hulpbronne dan mees doelmatige benut word en sal die produksie van beide kommoditeite styg (Lindert, 1996: 28).

Deelname in internasionale handel is tot voordeel van alle lande, selfs as 'n land absolute nadeel in alle kommoditeite besit. David Ricardo het daarop gewys dat indien so land sou spesialiseer in die kommoditeite waarin die absolute nadeel die kleinste is, relatief tot ander lande, en produkte invoer waarin sy absolute nadeel relatief die grootste is, sal alle lande se hulpbronne mees doelmatig aangewend word en die produksie van alle produkte toeneem. Deur die grootte van ' $n$ land se absolute nadeel met die van ander lande te vergelyk, kan 'n land vasstel watter produkte dit die mees doelmatigste produseer. In die produksie van sodanige kommoditeite besit ' $n$ land dan komparatiewe voordeel. Ricardo se idee is verder ontwikkel deur ander ekonome, maar die beginsel bly dieselfde (Krugman, 1991: 11-15).

Die Heckscher-Ohlinteorie gaan verder en poog om die oorsake vir die verskille in komparatiewe voordele tussen lande en kommoditeite te verklaar. Dit toon aan dat die produksiefaktore waaroor lande beskik verskil en dat die produksie van verskillende kommoditeite, verskillende kombinasies van hulpbron insette vereis. Internasionale verskille in produksiefaktore wat lande besit en die produksie tegnologie wat dit benodigde, lei tot verskille in relatiewe pryse en komparatiewe voordele in internasionale handel.

Die teorie stel dat 'n land kommoditeite wat met die relatief volopste produksiefaktore vervaardig word, sal uitvoer. Kommoditeite waarvan die produksie relatiewe skaars insette benodig, sal eerder ingevoer word. Indien land A byvoorbeeld oor relatief baie arbeid (L) beskik en land B baie kapitaalgoedere (K), is die prys van 'n eenheid arbeid relatief tot die prys van 'n eenheid kapitaal, laer in land $A$ as in land B; sodat 


$$
\therefore \mathbf{P}_{\mathbf{A}}{ }^{K} / \mathbf{P}_{\mathbf{A}}^{\mathbf{L}}<\mathbf{P}_{\mathrm{B}}{ }^{\mathbf{K}} / \mathbf{P}_{\mathrm{B}}^{\mathbf{L}}
$$

waar P die pryse van die insette is (Du Plessis, 1994: 47-48).

Die volopste produksiefaktore van 'n land kan ook bepaal word deur dit met die wêreldtotale te vergelyk. Indien land $A$ se volopste produksiefaktor arbeid is, sal:

$$
\mathbf{L}_{\mathbf{A}}{ }^{t} / \mathbf{L}^{t}>\mathbf{K}_{\mathbf{A}}{ }^{t} / \mathbf{K}_{\mathbf{w}}{ }^{t}
$$

waar $t$ alle produkte en $\mathrm{W}$ die res van die wêreld voorstel.

Kommoditeit $\mathrm{j}$ is dan land $\mathrm{A}$ se arbeidsintensiewe produk as:

$$
\mathbf{L}_{A}{ }^{l} / \mathbf{K}_{\mathbf{A}}{ }^{\prime}>\mathbf{L}_{w}{ }^{\prime} / \mathbf{K}_{\mathbf{w}}{ }^{2} \text {. }
$$

Aangesien kommoditeit $\mathbf{j}$ die intensiewe gebruik van land $A$ se relatiewe volop produksiefaktore benodig, lê land A se komparatiewe voordeel in produk $\mathbf{j}$.

\section{PROBLEME VAN VORIGE STUDIES}

Die Heckscher-Ohlinteorie vereis internasionaal vergelykbare data en wanneer die werklike aantal produksiefaktore in ag geneem word, raak die berekeninge te gekompliseerd om van praktiese waarde te wees. Internasionale produksiedata wat tegelykertyd in elke land met identiese navorsingsmetodes bepaal is en/of vergelykbare internasionale produktiwiteitstydreekse vir elke produk, is ook nie beskikbaar nie (Lindert, 1996: 64-67). Faktore soos die verskil in smaak, gehalte en dienslewering beïnvloed internasionale handelspatrone nog verder.

In 'n volmaakte wêreld met volmaakte mededinging, wat uit slegs twee lande en twee produksiefaktore bestaan, kan die Heckscher-Ohlinteorie kompara-tiewe voordeel maklik en akkuraat bereken word. In werklikheid is daar baie meer lande, bedrywe en produksiefaktore wat nie homogeen is nie en talle onvolmaakte markte. Berekeninge van internasionale komparatiewe voordeel, op grond van die Heckscher-Ohlinteorie, kan gevolglik nie 'n betroubare gids wees nie. 
Mededingendheid word omskryf as die vermoë van ' $n$ land om 'n markaandeel te bekom (Ortmann, 1988: 17). Verwante studies oor die landbou het meestal slegs na items soos kostes en wisselkoerse gekyk, soos die van Nieuwoudt (1986), terwyl ander net enkele bedrywe bestudeer het, soos byvoorbeeld die van Jooste \& Van Schalkwyk (1996). Daar was gevolglik nie bepaal watter landbouprodukte as internasionale wenners 'n mark aandeel kan bekom nie. Die doel met hulle navorsing het egter met die van die huidige artikel verskil. Daar bestaan ook probleme indien daar gepoog word om die tradisionele teoretiese beginsels, wat hierbo bespreek is, in die praktyk toe te pas.

\section{BALASSA SE METODE}

Om die meting van mededingendheid te verbeter en te vergemaklik stel Balassa (1989: 44-61) 'n berekeningsmetode voor wat hy Geopenbaarde Komparatiewe Voordeel noem. Individuele lande se komparatiewe voordeel word aangetoon deur hul handelsprestasies. Die patroon van handel in kommoditeite, openbaar al die faktore wat komparatiewe voordeel beïnvloed. Die bestaande handelspatrone openbaar gevolglik reeds die komparatiewe voordele van 'n land. Ontleding van ' $n$ land se internasionale handel verskaf sodoende akkurate inligting en riglyne vir die berekening van mededingende voordeel en vir die bepaling van beleid (Du Plessis, 1993: 158-160).

Ten einde komparatiewe voordele te bepaal, moet 'n land se handelsprestasies bestudeer word, om vas te stel wat 'n land se relatiewe aandeel in die wêrelduitvoer van individuele kommoditeite is; en hoe dit oor tyd verander. Die data word eerstens genormaliseer sodat dit vergelyk kan word. Die verhouding tussen ' $n$ land se relatiewe aandeel in die wêrelduitvoer, van 'n bepaalde produk, en die land se aandeel in die totale wêrelduitvoer word dan as ' $\mathrm{n}$ indeks uitgedruk. Ariovich (1979: 198) beskou Balassa se metode as meer toepaslik in die berekening van komparatiewe voordeel, aangesien daar aangeneem kan word dat die relatiewe uitvoeraandeel minder deur tariewe en ander beperkings versteur word, as in die geval van kostestrukture. Die uitvoeraandeel word net soos 'n markaandeel bereken, wat 'n algemeen aanvaarde kriterium vir bemarkingsprestasie is. Prakties is die metode maklik berekenbaar, die nodige data is beskikbaar en dit besit verklarings- en vooruitskattingswaarde.

Waar die tradisionele teorieë en vorige studies komparatiewe voordeel probeer bereken deur eers te bepaal watter faktore almal 'n invloed op die mededingendheid het, veronderstel Balassa dat die bestaande patrone en rigting van handel reeds die komparatiewe voordeel van 'n land openbaar. Die 
ontleding van 'n land se internasionale handel kan gevolglik akkurate inligting vir beleidsdoeleindes verskaf en oor tyd aantoon indien strukturele verandering in mededingendheid begin ontwikkel. Die bepaling van die komparatiewe voordeel van begin met ' $n$ ontleding van ' $n$ land se bestaande handelsprestasies.

Eerstens word die relatiewe aandeel (x) van, byvoorbeeld land A se uitvoer, in verhouding tot die wêrelduitvoer $(X)$, van byvoorbeeld produk $\mathbf{j}$ in die eerste periode bereken as:

$$
\left(X_{A j}{ }^{i} / X_{W j}^{i}\right) /\left(X_{A i}{ }^{i} / X_{W t}^{i}\right)=X_{A j}^{i} / X_{A}^{i}
$$

waar (i) die gemiddeld vir die eerste periode is, $t$ alle kommoditeite en $\mathbf{W}$ die wêreldtotaal is. Tweedens word die relatiewe aandeel van land A se uitvoer in die Wêrelduitvoer van produk $\mathbf{j}$ in die twee periode (ii) bereken as:

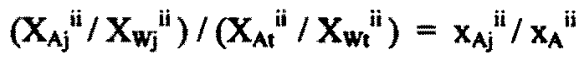

en derdens word die verhouding tussen die relatiewe aandeel in die tweede periode tot die relatiewe aandeel in die eerste periode bepaal as:

$$
\left(\mathrm{x}_{\mathrm{ij}}^{\mathrm{ii}} / \mathrm{x}_{\mathrm{A}}{ }^{\mathrm{ii}}\right) /\left(\mathrm{x}_{\mathrm{Aj}}^{\mathrm{i}} / \mathrm{x}_{\mathrm{A}}{ }^{\mathrm{j}}\right) \text {. }
$$

In die eerste twee stappe is aanwysers vir komparatiewe voordeel in twee periodes bereken en in die derde stap is om die verandering in relatiewe voordeel bepaal. Dit word dan gekombineer om 'n enkele indeks vir komparatiewe voordeel te bepaal. Die voortsetting van tendense kan geprojekteer word as die produk van vergelyking (2) en (3) en voorgestel word as:

$$
\left(x_{a j}^{i i} / x_{A}^{i i}\right) \cdot\left(X_{a j}^{i i} / x_{A}^{i i}\right) /\left(x_{A j}{ }^{i} / x_{A}^{i}\right)
$$

Die aanname is hier gemaak dat veranderinge in lande se relatiewe aandeel geometries groei en dan bloot geëkstrapoleer kan word. Balassa (1989: 46) stel voor dat dié aanname met 'n kompromie gedeeltelik vermy kan word, indien die gemiddeld van vergelykings (2) en (4) geneem word as:

$$
1 / 2\left[\left(x_{a j} i i / x_{A}^{i i}\right)+\left(x_{a j}{ }^{i i} / x_{A}{ }^{i i}\right) \cdot\left(x_{a j}{ }^{i i} / x_{A}{ }^{i i}\right) /\left(x_{A j}{ }^{i} / x_{A}{ }^{i}\right)\right]
$$

Kortweg:

$$
1 / 2\left[\left(x_{a j}{ }^{i i} / x_{A}{ }^{i i}\right)+\left(x_{a j} i j / x_{A}{ }^{i i}\right)^{2} /\left(x_{A j}{ }^{i} / x_{A}{ }^{j}\right)\right] \text {. }
$$

(Balassa, 1989: 53). 
Die aanname van die kompromie-oplossing is dat daar steeds verwag word dat vorige tendense sal voortduur, maar teen 'n dalende koers. Vergelyking (5) word nou gebruik om indekse vir elke kommoditeit te bereken wat as maatstaf kan dien in die bepaling van komparatiewe voordeel.

Deur middel van 'n eenvoudige toetsmodel is aangetoon dat 'n produk met indekssyfer groter as een komparatiewe voordeel geniet, terwyl indekssyfers kleiner as een 'n komparatiewe nadeel verteenwoordig. 'n Kommoditeit wat geen komparatiewe voordeel of nadeel besit nie is as toetsmodel gekies. 'n Indekssyfer gelyk aan een vorm die afsnypunt. Indien dit gelyk aan een is, lê die absolute waarde, van die produk se aandeel in internasionale uitvoere, op die kritieke grens omdat die produk se aandeel in die land se uitvoer, gelyk is aan sy aandeel in wêrelduitvoer. Daar vind dan geen markindringing of -verlies plaas nie, aangesien die kommoditeit se relatiewe aandeel nie tussen die twee opeenvolgende periodes verander nie.

\section{Komparatiewe Voordeel in die Suid-Afrikaanse Landbou}

Balassa se metode is van besondere praktiese waarde. A Wentzel, ekonoom by die Departement van Landbou, het Balassa se metode toegepas in 'n studie van die komparatiewe voordeel van die Suid-Afrikaanse landbou en verwante bedrywe (1994). Met die metode is onder andere aangetoon dat die landbou se grootste komparatiewe voordeel in onverwerkte wol gesetel is. Daarna volg, in volgorde, chemiese houtpulp, druk- en skryfpapier, vrugte, huide en velle en heel mielies met 'n geringe voordeel. Enkele van die produkte word in Tabel 1 getoon. Die indeks toon internasionale komparatiewe voordeel indien dit groter as een is, en komparatiewe nadeel as die indeks kleiner as een is.

Balassa se konsep van geopenbaarde komparatiewe voordeel is op die SuidAfrikaanse landbou, vir die periode van 1981 tot 1987 , toegepas deur van gestandariseerde internasionale handelsdata van die United Nations Internasional trade Statistics Yearbook gebruik te maak (Wentzel, 1994: 10). In die jaarboek word afsonderlike lande se invoer- en uitvoersyfers van elke kommoditeit gegee. Die kommoditeite word in syfergroepe geklassifiseer, wat 'n breë klassifikasie is en wat weer onderverdeel is in twee tot vyf groepe. Dié data was gekies aangesien dit die enigste beskikbare gestandardiseerde handelsdata is wat beskikbaar was. 
Komparatiewe Voordeel van Suid-Afrikaanse Landbouprodukte: 1981 $-1987$

\begin{tabular}{|c|l|c|}
\hline Rangorde & \multicolumn{1}{|c|}{ Kommoditeit } & Indeks \\
\hline 1 & Wol (ontghries en nie-gekam) & 38,17 \\
2 & Chemiese houtpulp & 18,58 \\
3 & Druk- en skryfpapier & 16,69 \\
4 & Lemoene (vars en gedroog) & 8,70 \\
5 & Vars appels & 8,06 \\
6 & Natrium Kalsium fosfate & 7,24 \\
7 & Wol (met ghries, skeersel gewas) & 6,82 \\
8 & Huide, velle (rou, pels uitgesluit) & 5,46 \\
9 & Druiwe (vars en gedroog) & 4,23 \\
10 & Suiker en heuning & 3,99 \\
11 & Ingemaakte vrugte & 3,35 \\
12 & Mielies (ongemaalde pitte) & 3,01 \\
13 & Rou beet en rietsuiker & 2,04 \\
14 & Sintetiese vesel & 1,32 \\
15 & Koerantpapier & 1,31 \\
16 & Wol (verwerk) & 1,13 \\
17 & Veevoer & 0,57 \\
18 & Vleis (vars, verkoel en gevries) & 0,35 \\
\hline Sleutel: Indeks >1 toon komparatiewe voordeel. & \\
\hline & Indeks <1 toon komparatiewe nadeel. & \\
\hline
\end{tabular}

Bron: Wentzel, 1994: 11-12.

Daar bestaan 'n groot internasionale komparatiewe voordeel in vars en gedroogde vrugte, asook ingemaakte vrugte met onderskeidelik indekse van 3,49 en 3,35, asook die wolbedryf wat 'n algemene indeks van 6,11 het. Dit is opvallend dat verwerkte wol slegs ' $n$ indeks van 1,13 het. Ru-kunsmis besit die grootste individuele voordeel van 6,18 , terwyl die suikerbedryf 'n matige voordeel van 3,99 het, en mielies 3,01. Papier- en verpakking toon gemengde resultate met indekse van 4,13 en 1,67 onderskeidelik. Anders as wat verwag sou word besit die vleisbedryf, van die grootste komparatiewe nadele in die Suid-Afrikaanse ekonomie $(0,35)$, maar in dierevelle het die land een van die grootste komparatiewe voordele met ' $n$ indeks van 5,46 . Veevoer besit 'n komparatiewe nadeel van 0,59 , terwyl die komparatiewe nadeel in koring so groot is dat dit nie 
eens genoem word nie. Suid-Afrika het natuurlik 'n absolute voordeel in die produksie van rooibostee omdat die land die enigste produsent is. Breedweg stem dié resultate ooreen met sommige bevindings van Ariovich (1979), alhoewel sy studie nie slegs op die landbousektor gefokus het nie.

In die lig van veranderde toestande in die wêreld kan daar verwag word dat die indeks in die toekoms baie sal verander en volgehoue navorsing in die verband is nodig, so gou as wat nuwe data beskikbaar word. Met minder beskerming mag mielies byvoorbeeld swakker vaar, aangesien dit oorsee hoofsaaklik as veevoer gebruik word. Indien die subsidiëring van landbouproduksie in die Verenigde State en die Europese gemeenskap werklik uitfaseer gaan word, kan dit moontlik weer die Suid-Afrikaanse landbou uitvoer bevoordeel. Indien tariewe verlaag mag die invoer van wol vanaf Australië meer winsgewend raak, maar indien dieselfde situasie in alle markte geld mag Suid-Afrikaanse wol dieselfde voorregte smaak. Die algemene gevoel is dat die uitvoering van die AOTHooreenkoms die uitvoer van Suid-Afrikaanse rooivleis na Westerse lande gaan bevoordeel, maar dieselfde geld vir die uitvoer van Australiese, Amerikaanse en Europese vleisuitvoere. Daar kan gevolglik nie vooraf bepaal word in watter opsig internasionale mededingendheid deur die veranderende wêreld toestande geraak gaan word nie. Mettertyd sal die volgehoue berekening van indekse wel bepaalde tendense aandui.

'n Tekortkoming van Balassa se metode is dat kommoditeite waarvoor daar nie handelsdata bestaan nie, en kommoditeite wat nie uitgevoer word nie, geïgnoreer word. Suid-Afrika het byvoorbeeld 'n absolute voordeel in rooibostee, maar dit word nie by die ontleding ingesluit nie weens ' $n$ gebrek aan intemasionale data. In talle lande is die data vir die berekening van komparatiewe voordele egter uiters ontoereikend. Vanweë die hoë vlakke van beskerming en owerheidsondersteuning wat handelspatrone versteur, veral in die Verenigde State en die Europese Unie, is 'n ontleding van komparatiewe voordele in die landbou nie altyd baie betroubaar nie.

\section{Verdere en Verwante Navorsing}

Hierdie ondersoek was ' $n$ eerste stap in die ontleding van die internasionale mededingendheid van die Suid-Afrikaanse landbousektor, waarin Balassa se metode toegepas is. Ten einde ' $n$ beter aanduiding van die komparatiewe voordeel in bepaalde produkte in die sektor te verkry, behoort soortgelyke indekse, van die land se belangrikste mededingers, ook bereken te word. Dit kan ook aantoon waar moontlikhede vir ekonomiese integrasie bestaan en wat die effek daarvan sal wees. Ook in die breë Suider-Afrikaanse ontwikkelingskonteks sal die berekening van sodanige indekse kan aantoon waar ekonomiese integrasie 
tussen SADC-lande die voordeligste sal wees. Soortgelyke studies behoort ook vir ander sektore, soos byvoorbeeld vervaardiging, uitgevvoer te word, (sien byvoorbeeld Ariovich (1979 \& ' 80 ).

Indien die Heckscher-Ohlinteorie gebruik wil word om komparatiewe voordeel te bereken ten einde die resultate van die Balassa-metode te bevestig, sal meer data ingesamel moet word. Hier in besonder is inligting rakende die totale voorraad produksiefaktore wat benodig word per kommoditeit, beide op 'n provinsiale en nasionale vlak, nodig. Die data wat in hierdie artikel gebruik was om die mededingendheid van Suid-Afrikaanse landbou te illustreer is natuurlik onvoldoende, maar by ' $n$ gebrek aan plaaslike data was data van die Verenigde Nasies gebruik. Vir verdere ontledings sal data van die $\mathrm{VN}$ ook op gedateer moet word.Vir vergelykende studies sal dit egter beter wees om van dieselfde metodes gebruik te maak. In die verband kan die huidige studie byvoorbeeld met dié van Ariovich (1979) vergelyk word wat ook Balassa se metode, vir die periodes 1973 tot 1975 , gebruik het. Dit gaan veral in die toekoms van nut wees on te monitor in watter mate kommoditeite se mededingendheid gaan verander soos wat die AOTH besluite in werking tree en tariewe en invoerbeheermaatreëls gaandeweg afgeskaal word.

Ondersoeke na verdere periodes en eksperimente rakende die lengte van die periodes van ondersoek, mag van waarde wees om kennis en begrip van die mededingende situasie te vergroot. Dit sal van waarde wees indien die studie vir die tydperk na 1987 ook uitgevoer kan word, sodra die nodige data beskikbaar is, sodat vergelykings moontlik kan wees. Daar kan dan bepaal word watter veranderinge in mededingendheid aan die ontwikkel is in die verskillende kommoditeite. Veral waar tariewe en invoerbeheer nou afgeskaal word. Dit sal interessant wees om indekse van jare waar tydens daar 'n groot mate van proteksionisme aanwesig was, soos in die jare sewentig, te vergelyk met periodes na die inwerkingstelling van die AOTH- ooreenkomste. Indien die ontwikkeling in die jare wat voorlê noukeurig gemonitor word, kan daar vroegtydig tendense bepaal word en opgetree word om skokke te vermy. Te kort periodes mag moontlik te min inligting verskaf en in dieselfde rigting dui weens ewekansige gebeure, soos droogtes, die uitvoersituasie in uitvoerlande in die korttermyn en skommeling in kostes en pryse. Te lang periodes sal weer hul eie nadele hê. Die studie kan ook na meer periodes uitgebrei word, sodat tendense wat moontlik op sigself belangrik mag wees, ondersoek kan word.

Verdere navorsing wat kan aandui wat sommige kommoditeite meer mededingend as ander maak, kan uit hierdie studies voortspruit. Die moontlikheid om produkte, wat reeds komparatiewe voordeel geniet, se mededingendheid verder te verstek kan ondersoek word. Navorsing rakende 
sodanige kommoditeite, mag aantoon op watter wyse ander produkte ook meer mededingend kan word. Produkte wat nie komparatiewe voordeel geniet nie, behoort ondersoek te word om vas te stel wat vir hul verlies aan mededingendheid verantwoordelik is en hoe sodanige produkte, waar moontlik, meer mededingend gemaak kan word. Kommoditeite waarvan die komparatiewe voordele nie verbeter kan word nie, behoort vermy of ontmoedig te word. Dit mag egter nie plaasvind alvorens die ekonomiese en sosiale kostes, wat 'n staking of verlaging in produksie daarvan sal meebring, bereken is nie, veral omdat landbou kommoditeite soveel skakeleffekte met die res van die ekonomie het. Die resultate van studies behoort aan intensiewe ondersoeke onderwerp te word. So byvoorbeeld sal daar na aanleiding van dié studie oor die landbou, intensief gekyk moet word na die vrugte-, wol- en vleisbedryf.

Hierdie studie stem saam met studies rakende ander Suid-Afrikaanse bedrywe, soos byvoorbeeld die motorbedryf (Van Zyl: 1995: 8), in die opsig dat SuidAfrikaanse arbeid nie internasionaal mededingend is nie. Suid-Afrika het byvoorbeeld 'n komparatiewe voordeel in vuil onverwerkte wol, maar sodra arbeid bygevoeg word, om dit byvoorbeeld te was of te kam, verloor die land sy mededingende voordeel. Dit kom daarop neer dat arbeid nie produktief genoeg is nie en produsente nie waarde vir hulle geld ontvang, wanneer arbeidsintensiewe tegnologie geïmplementeer word nie. In die verband het Ariovich (1979: 192) ook gevind dat komparatiewe voordeel in Suid-Afrika geleë is in produkte wat kapitaalintensief is. Met so groot werkloosheidsyfer sou dit vir die land beter gewees het indien mededingende voordele in arbeidsintensiewe produksie behaal kon word.

Kritiek teen die voorgestelde metode van Balassa is dat dit die bestaande handelspatrone weerspieël en om dit getrou te kan weergee moet handelspatrone goed ontwikkel wees, produksiekostes nie versteur wees en en moet die vrye markmeganisme behoorlik funksioneer. Indien dit nie die geval is nie, soos wat tans nog die geval is met distorsies en handelsbeperkinge, is die "Competitive advantage" benadering van Porter meer gepas. 'n Ontleding gebaseer op die "Policy Analysis Matix" (PAM) sou waarskynlik ook meer sin gemaak het. Met die vele beperkinge en subsidies tot onlangs in die SuidAfrikaanse landboumark, toon Balassa se metode nie werklik die potensiaal van die sektore nie en eerder slegs hoe die situasie in die wêreldekonomie was, te midde van subsidies, sanksies, kwotas en ander beskermingsmaatreëls.

Dit is juis ook weens die beginsel van geopenbaarde voordeel, instaat om ekonomiese ontwikkeling aan te toon. Waar die bepalings van die AOTH tans inwerking tree en internasionale handelsliberalisasie al meer veld wen, kan Balassa se metode juis van waarde wees om die groeiende potensiaal van 
sommige produkte en sektore aan te toon, terwyl sommige voormalige wenners aan die kwyn is. Die voordeel van Balassa se metode lề egter daarin dat dit maklik, vinnig en ekonomies is om te bereken.

\section{SAMEVATTING}

Die doel van die artikel is om 'n alternatiewe metode van meting en kwantifisering van internasionale mededingendheid voor te stel. Die bepaling van komparatiewe mededingendheid is belangrik omdat die patroon van internasionale handel en die allokasie van hulpbronne daarvan afhang. Die praktiese toepassing van die tradisionele teorieẽ word aansienlik bemoeilik deur werklike data en ander probleme. Om dit te oorkom word daar in hiérdie artikel voortgebou op Balassa (1989) se voorstel dat komparatiewe voordeel aan die hand van histories geopenbaarde voordeel gemeet kan word.

Die Suid-Afrikaanse landbousektor is as 'n gevalle studie gebruik vanweë die groot aandeel wat die landbousektor tot die land se bruto binnelandse produk lewer, die feit dat landbou is 'n goeie verdiener van buitelandse betaalmiddele is en groot skakeleffekte wat bestaan. Gedurende die laaste tien jaar het landbouuitvoer ongeveer agt persent van die land se uitvoer uitgemaak. Selfs in die swakste jare en tydens die sanksie-era was die landbou 'n netto uitvoerder. Met die toenemende neiging tot internasionale handelsliberalisering is dit noodsaaklik dat daar bepaal word op watter terreine die Suid-Afrikaanse landbou komparatiewe voordele besit. Weens die sosiale en strategiese belangrikheid van die landbousektor vir die Suid-Afrikaanse ekonomie behoort enige verandering in die produksie en mededingendheid van 'n kommoditeit aan deeglike kostevoordeel analise onderwerp te word.

In hierdie studie is indekse volgens Balassa se metode bepaal wat aantoon in watter produkte die Suid-Afrikaanse landbou komparatiewe voordeel het. 'n Indeks groter as een dui op komparatiewe voordeel. Die grootste mededingende voordeel is in onverwerkte wol, houtpulp, druk- en skryfpapier en vrugte. Opvallend is dat die komparatiewe voordeel op koerantpapier, verwerkte wolprodukte en suiker taamlik laag is. Wat onverwags was, is die land se komparatiewe nadeel in vleisproduksie.

Hierdie studie stem saam met studies rakende ander Suid-Afrikaanse bedrywe, soos byvoorbeeld die motorbedryf (Van Zyl: 1995: 8), dat Suid-Afrikaanse arbeid nie internasionaal mededingend is nie. In die verband stem Ariovich (1979: 192) saam dat Suid-Afrika slegs komparatiewe voordeel geniet in kommoditeite wat kapitaalintensiewe produksie tegnieke benut. Suid-Afrika het byvoorbeeld 'n 
komparatiewe voordeel in vuil onverwerkte wol, maar wanneer arbeid bygevoeg word, om dit byvoorbeeld te was, verloor die land sy mededingendheid. Dit kom daarop neer dat arbeid nie produktief genoeg is nie en produsente nie waarde vir hulle geld kry, wanneer arbeidsintensiewe tegnologie geïmplementeer word nie. Met die groot werkloosheidsyfer is dit van kardinale belang dat die land se arbeidsproduktiwiteit en werksetiek daadwerklik, deur middel van opleiding en opvoeding, verhoog sal word.

Balassa se berekeningsmetode vir komparatiewe voordeel is relatief eenvoudig, benut beskikbare data en word as meer geskik beskou (Ariovich, 1979: 189). Dit kan met vrug benut word in ander sektore soos byvoorbeeld in aspekte van nywerheidsontwikkeling en kan ook 'n nuttige doel dien by die beplanning van streeksintegrasie binne die Suid-Afrikaanse Ontwikkelingsgemeenskap. Uit die studie behoort baie navorsing te spruit, wat van groot waarde vir die landbou en die Suid-Afrikaanse ekonomie as geheel sal wees.

\section{EINDNOTA}

1 Prof. SJ van der Merwe van die Potchefstroomse Universiteit vir Christelike Hoër Onderwys word bedank vir sy insette by die skryf van hierdie artikel.

\section{VERWYSINGS}

1. ANDERSON, K \& TYERS, R (1991). Global Effects of Liberalising Trade in Ffarm Products. New York: Harvester/Wheatsheaf. $\mathrm{p} 99$.

2. ANON. (1984). Africa's Empty Belly. Economist. 11 February 1984. pp 18-19.

3. ANON. (1989). GATTling Gun for Farms. Economist. 8 July 1989. pp 1516.

4. ARIOVICH, G. (1979). The Comparative Advantage of South Africa as Revealed by Exports. Suid-Afrikaanse Tydskrif vir Ekonomie. 47(2): 188197.

5. ARIOVICH, G. (1980). A Note on Export Shares and Capital-Intensity in South African Industry. Suid-Afrikaanse Tydskrif vir Ekonomie. 48(2): 211-213.

6. BALASSA, B. (1989). Comparative Advantage, Trade Policy and Economic Development. London: Harvester/Wheatsheaf. 187p.

7. BISHOP, C.E. \& TOUSSAINT, B. (1958). Introduction to Agricultural Economic Analysis. London: Wiley. 258p. 
8. DE KOCK, J.H.W. \& LAUBSCHER. J. (1993). Die Relatiewe Mededingendheid van die Suid-Afrikaanse Koringbedryf met betrekking tot die Internasionale Koringmark. Agrikon 32(1): 24-30.

9. DEPARTEMENT VAN LANDBOU (1994). Algemene Ooreenkoms oor Tariewe en Handel. Agtergrond en Implikasies vir Suid-Afrika. Pretoria: Departement van Landbou: Direktoraat Bemarking. 21p.

10. DU PLESSIS, S.P.J; SMIT, B.W. \& McCARTHY, C.L. (1993). Intemational Economics. Durban: Butterworths. 320p.

11. JOOSTE, A. \& VAN SCHALKWYK, H.D. (1996). Beef Trade Preferences and Intensities in the South African Customs Union. Agrikon. 35(3): 123-130.

12. JOOSTE, A. \& VAN SCHALKWYK, H.D. (1996). The Impact of Different Macro-economic Variables on the Optimal Distribution of Beef in the Southern African Customs Union. Agrikon. 35(4): 276-282.

13. KRUGMAN, P. R. \& OBSTFELD, M. (1991). International Economics, Theory and policy. New York: Harper Collins. 682p.

14. LINDERT, P.H. \& PUGEL, T.A. (1996). International Economics. Chicago: Irwin. 679p.

15. MEIER, G.M. (1989). Leading Issues in Economic Development. 5 ed. New York: Oxford University Press. 560p.

16. MELLOR, J.W. (1966a). Economics of Agricultural Development. New York: Comell University Press. 403 p.

17. MELLOR, J.W. (1966b). Economics of Agricultural Development. an Adaptation. Bomby: Vakils. 150p.

18. NIEUWOUDT, W.L. (1986). Die Mededingende Posisie van die SuidAfrikaanse Landbou: 'n Ontleding van vraag en aanbod. Agrikon. 25(3): $34-41$.

19. NUPPENAU, E.A. (1994). Regional Trade and Pricing of Maize in Southem Africa. Agrikon 33(4): 175-183.

20. ORTMANN, G.F. \& RASK, N. (1988). Die Kostemededingendheid van Belangrikste Uitvoerlande ten opsigte van Mielies, Koring en Sojabone. I: Produksie- en Bemarkingskoste. En artikel II: Koste aan Wal en die Uitwerking van Wisselkoerse. Agrikon. 27(2): 17-30.

21. ROSINE, J; WALRAVEN, N. \& OTT, M.J. (1991). Update on the Farm Economy. Federal reserve bulletin. December 1991. pp 967-979.

22. SUID-AFRIKAANSE LANDBOU-UNIE. (1982). Mededingendheid van die Landbou en die Invloed van Beskerming van Binnelandse Nywerhede daarop. Veranderings in die Pariteitsposisie van die Suid-Afrikaanse landbou. Dok 282/82.

23. THIRLWALL, A.P. (1989). Growth and Development. 4 ed. London: MacMillan education. $567 \mathrm{p}$. 
24. THORBECKE, E. (1969). Role of Agriculture in Economic Development. New York: Columbia University Press. 480p.

25. TUTT, N. (1989). Export Fiddles and Retirement Scams. Accountancy, March 1989. pp 18-19.

26. UNITED NATIONS INTERNATIONAL TRADE STATISTICS YEARBOOK. Various editions (1983-91). New York: UN.

27. VAN ROOYEN, C.J. (1990). Agricultural Restructuring in Southem Africa: The Contribution of the Developing Agricutural Sector. Agrikon. $29(1)$.

28. VAN ZYL, G. \& KLEYNHANS, E.P.J. (1995). "A Cobb-Douglas Estimation of Labour Productivity in the South African Motor Vehicle Industry". Journal of Industrial Psychology. 21(1): 6-9.

29. WENTZEL, A. (1994). Komparatiewe voordeel van die Suid-Afrikaanse Landbou en Verwante Bedrywe. Pretoria: Departement van Landbou: Direktoraat Landbou-ekonomiese tendense. $17 \mathrm{p} . \quad 90$ 


\section{CALL FOR PAPERS}

\section{BIENNIAL CONFERENCE OF THE ECONOMIC SOCIETY OF SOUTH AFRICA}

\section{INTERNATIONAL CAPITAL FLOWS, EMERGING MARKETS AND SOUTH AFRICA}

The Society will hoid its biennial conference at Pretoria University on 6 and 7 September 1999. Papers will be read around the conference theme of International Capital Flows, Emerging Markets and South Africa. Contributions are invited from economists working in this field.

Papers may be submitted on other topics too; these will be presented in parallel sessions.

A preliminary draft of the proposed paper, not more than 250 words, must reach the Programme Committee by 31 March 1999 at: ESSA Programme Committee. Department of Economics, University of Pretoria, Pretoria 0002, South Africa.

\section{UITNODIGING VIR REFERATE}

\section{THEGAAALIKS KONFERENSIE VAN DIE EKONOMIESE VERENIGING VAN SUID-AFRIKA}

\section{INTERNASIONALE KAPITAAVVOEIE, ONTLUIKENDE MARKTE EN SUID- AFRIKA}

Die Vereniging se tweejaarlikse konferensie sal gehou word by die Universiteit van Pretoria op 6 en 7 September 1999. Referate sal gelewer word rondom die kongrestema van Internasionale Kapitaalvloeie, Ontluikende Markte en Suid-Afrika. Ekonome wat op hierdie gebied werk, word genooi om bydraes te lewer.

Referate oor ander onderwerpe, wat in gelyktydige sessies aangebied sal word, is ook aanvaarbaar.

'n Voorlopige konsep van die voorgestelde referaat van hoogstens 250 woorde moet die EVSA Programkomitee bereik voor 31 Maart 1999 by die Departement Ekonomie, Universiteit van Pretoria, Pretoria 0002. 